C $|\mathbf{O}| \mathbf{P} \mid \mathbf{E}$ JM14482
Dyskusje / polemiki / recenzje

Lech Witkowski*

\title{
Przekroje profesjonalności: reprezentacje versus transformacje
}

\begin{abstract}
Abstrakt
Tekst omawia zawartość tomu: Représenter/transformer. Débats en analyse des activités, koord. Jean-Marie Barbier, Marc Durand, Paris 2018.

Wątki rozważań: antropologiczne; teatralizacja, metaforyzacja, cielesność, niewidzialność, milczenie, gesty i przedmioty techniczne; poziomy i style, analogie i regularności w służbie transformacji, uwikłania w wiedzę i instalacje. Warianty upodmiotowienia.
\end{abstract}

Słowa kluczowe: transformacje, techniczność, reprezentacje, poziomy, inwarianty.

\section{Cross-sections of Professionalism: Representations versus Transformations}

\begin{abstract}
The text discusses the content of the volume: Représenter/transformer. Débats en analyse des activités. Ouvrage coordonné par Jean-Marie Barbier et Marc Durand, Paris 2018.

Issues considered: the anthropological; theatricality, metaphorization, carnality, invisibility, silence, gestures and technical objects; levels and styles, analogies and regularities in the service of transformation, entanglement in knowledge and installations. Variants of empowerment.
\end{abstract}

Keywords: transformations, technicity, representations, levels, invariants.

\footnotetext{
* Akademia Pomorska w Słupsku.

Artykuł otrzymano: 7.02.2021; akceptacja: 13.04.2021.
} 


\section{Wstęp}

Jean-Marie Barbier jest uznanym badaczem i inicjatorem refleksji wokół podstaw myślenia humanistycznego w zakresie problematyki aktywności ludzkiej i niezbędnych - dla niej i w niej - kategoryzacji. Jego analizy wpisują się w interesująco rozwijaną przez siebie wieloprofilową perspektywę, którą sam określa mianem „antropologia praktyki profesjonalnej”, czemu dał wyraz m.in. w niedawno przetłumaczonym w Polsce tomie Leksykonu analizy aktywności (Barbier 2016, 2017). Szczególną zasługę w udostępnianiu tej perspektywy ma w Polsce od lat współpracująca z Barbierem i bardzo aktywna w środowiskach pedagogiki frankofońskiej we Francji i w Kanadzie Ewa Marynowicz-Hetka, czołowy polski pedagog społeczny, również pracująca nad podstawami teoretycznymi dyskursu pedagogicznego w polu praktyki społecznej (Marynowicz-Hetka 2019, 2020). Współpraca ta okazuje się bardzo wartościowa poznawczo i przynosi istotne owoce. Poniżej daję temu wyraz z własnej perspektywy.

Niedawno ukazała się, wspomniana już wyżej, ważna i cenna książka (Représenter/transformer. Débats en analyse des activités, 2018), zbierająca rozważania międzynarodowego grona współpracowników Barbiera. Pogłębia ona rozumienie styku transformacji i reprezentacji, które jako dwa aspekty aktywności profesjonalnej muszą sprzęgać się ze sobą, rzutując w różnych przekrojach relacji zarówno na jakość refleksji, dynamiki, struktury, jak i zdolności do korekty i innowacji w procesach działania i ich percepcji ze strony uczestników tychże.

Książka zawiera teksty zaskakująco dopełniające się, przynoszące zarówno konkretne ilustracje wybranych sfer działania, jak i uogólnienia teoretyczne, ważne szerzej. Szczególnie cenne wydaje się to, że podejmują one tematykę aktywności przez pryzmat zwykle jednego kluczowego, dominującego pojęcia i/lub obszaru jako ramy dla prześwietlenia zakresu działania, które staje się sposobem ekranizacji złożoności wybranego aspektu praktyki profesjonalnej. Tym zaskakującym dla mnie samego spostrzeżeniem się kierując, dokonuję selekcji wątków książki pozwalających na zestawienie takich zasadniczych motywów, dominujących w zakresie reprezentowania transformacji w praktykach profesjonalnych. W sześciu częściach zebranych jest 13 tekstów uwypuklających wybrane aspekty analizy metanarracyjnej, które tu skrótowo przywołam, a dotyczące różnorodnych relacji między tytułowymi członami książki. Podejmuję więc próbę wykorzystania głównych rysów rozważań autorów książki dla zarysowania problemów pola aktywności profesjonalnej $\mathrm{w}$ moim ich ujęciu (reprezentacji), choć z możliwie wiernym wykorzystaniem relacjonowanych narracji (z przywoływaniem dla precyzji czasem istotnych terminów francuskich). Tekst tego eseju zakończę pewnymi uwagami krytycznymi i postulatami w kierunku dalszej transformacji dyskursu. Warto podkreślić międzynarodowy charakter projektu wieńczonego tę publikację zbierającą prace autorów z: Brazylii, Francji, Kanady, Polski, Szwajcarii, Wielkiej Brytanii i Włoch. Polską pedagogikę reprezentuje jako jedyna Ewa Marynowicz-Hetka w tekście ważnym epistemologicznie. 


\section{Ku antropologii działania}

I tak w swoim tekście, otwierającym książkę, Jean-Marie Barbier (2018) uczula na dwa wymiary zmian $w$ transformacji: jeden dotyczy przechodzenia ze stanu w stan w obrębie samego procesu; drugi przejawia się jako zmiana przebiegu samego procesu, jako przebiegu będącego przedmiotem transformacji, przynoszącego efekty na niższym poziomie powstających stanów. Analizy podjęte w tekście wymagają podejścia pozwalającego na uwzględnianie także sprzężeń sytuacyjnych oraz dotyczą relacji odniesionych do dyspozycji podmiotów w transformacje uwikłanych. Transformacje procesów nie dadzą się wyjaśniać na poziomie samych cech składników wchodzących w nich w grę, zważywszy na zjawiska emergencji - powstawania nowych jakości, wcześniej niemożliwych. Chodzi więc o pojawianie się nowych czynników, wynikłych np. z powiązań czy sprzężeń (couplages) zespalających wcześniej odrębne lub nieobecne czynniki, przemieszczeń w poprzek (transversales) wcześniejszych podziałów czy świadomie inicjowanych nowych konstrukcji w strukturze procesów, nie wyłączając zjawisk przeciwstawnych jak rozpady czy pęknięcia albo podziały struktur wcześniej występujących jako całości funkcjonalne. Szczególnie uwypuklony okazuje się aspekt „antropologii aktywności” dopełniający ją o „antropologię aktywności myślowej” podmiotów, z którymi, dla których jak i na których (wobec których) praktyki i procesy mają miejsce, za każdym razem w innym przekroju zjawisk i wyzwań. Ważnym aspektem tej nowej perspektywy jest uwzględnianie sprzężeń między zwykle rozdzielanymi sferami afektywności podmiotowej i zdolności odnoszenia się do działania poza jego intencjami (celowym ukierunkowaniem) i innymi składowymi tożsamości uczestników procesów. Niezbędne jest sprzęganie refleksyjności na poziomie operacji i na poziomie uzyskiwanych ich produktów, ze zdolnością do „uprzedmiatawiania” (réification) stanów, zwykle widzianych jedynie jako emanacja podmiotowości. Rozmaitość zdwojeń i podziałów w odniesieniach do konstrukcji i niezależnych od nich aspektów działań i procesów obejmuje także skalę wagi nadawanej doświadczeniu wyłaniającemu się $\mathrm{w}$ takiej dynamice i jego ewentualnej stabilizacji w praktyce powstawania przestrzeni treści podzielanych przez uczestników procesu.

W grę więc wchodzi najwyraźniej nowy „model epistemologiczny”, wymagający porzucenia (abandonner) dominującego podejścia, zajmującego się linearnymi i jednokierunkowymi odniesieniami do przyczynowości i determinacji w sferze procesów i praktyk profesjonalnych. W grę wchodzą korelacje, logika wzajemności uwikłanych w sprzężenia i mediacje podmiotowe obejmujące podwojenia (doublement), rzutujące na dynamikę przebiegów i ich charakterystykę. Niezbędne jest możliwie świadome i krytyczne posługiwanie się konstrukcjami w sferze aktywności i reaktywności podmiotowych uczestników relacji uruchamiających i korygujących mobilności funkcjonalne. 


\section{Kwestia inwariantów i regularności}

Na przykładzie ergonomii autorka Cécile Barbier (2018) porusza szerszą kwestię jawnego lub wprost niewyrażanego, milcząco obecnego (tacitement) sprzęgania z szerszą rodziną odniesień do konstrukcyjnej aktywności człowieka. Uwypukla rozmaite „podwójne orientacje”, wymagające uwzględniania możliwości transformacji także w sferze „inwariantów” zakładanych na wcześniejszym etapie doświadczenia łączącego aktywność z wyobrażeniem o powstającym środowisku. Dzieje się to przy odejściu od (wręcz zerwaniu z) tradycyjnych nastawień laboratoryjnych zamiast realnej praktyki, wymagające postawy epistemologicznej upominającej się o ambiwalencje, uwalniającej od dominujących stereotypów dyktowanych przez zakres wykorzystywanych narzędzi i zamykających dostęp do innowacji w skojarzeniach konstruujących nowe obiekty realne. Postawa poznawcza pozostać ma otwartą wobec nieprzewidywalnych wariantów, stanowiąc rodzaj nowego zobowiązania etycznego $\mathrm{w}$ zakresie dopuszczającym transformację jako przestrzeń działania. Chodzi o epistemologię stającą się otwarciem na ekologię o nowej pojemności w zakresie relacji i konstrukcji spoza świata treści i form znanych i uznanych.

W grę wchodzi kwestia trwałości i ogólności w obliczu zderzania regularności i wstrząsów w zakresie ich wystarczalności. Inwarianty pozostają tymczasowe, względne, dostosowane do ram wcześniejszego doświadczenia, związanego z praktyką zawodową i nastawieniami uczestników (użytkowników/adresatów oraz twórców/wytwórców). Inwarianty muszą być w działaniach wytwórczych postrzegane poza stereotypami nastawień, dopuszczając przekraczanie wyobrażeń przy jednoczesnym unikaniu zdrady funkcji użytkowej/przydatności w praktyce życiowej danego zakresu. Ważne okazuje się uwalnianie od dualizmów, zastępowanie bipolaryzacji przeciwstawiających przedmioty i użytkowników nowemu rodzajowi złożonej strukturalnie całości organicznej, powstającej w „dialektyce” pozwalającej na relacyjne łączenie siebie w integralną całość własnego środowiska, gdy habitus nawyku użytkowego dopuszcza prototypy nowych relacji, opartych na zerwaniu (rupture) z nawykami, najpierw w sferze poznania (projektów), a dalej w sferze działania (konstruowania nowej ekologii). Warunkiem pozostaje troska o równoważenie (l'équilibre) w relacji człowieka do jego środowiska za cenę, znaną jeszcze psychologii Piageta, uwzględniającej procesy określane mianem akomodacji struktur i adaptacji do struktur. Ta dialektyka przetworzeń jawi się jako nie do pominięcia przy podchodzeniu do inwariantów wystawionych na zmiany poza wcześniejszymi ramami możliwości wytwórczych (technik, środków) i uelastyczniania relacji, w jakich uczestniczy człowiek. Transformacje obejmują możliwości robienia czegoś „inaczej” jak i postrzegania nowej relacji za cenę zerwania z nawykami wpisanymi we wcześniejszą praktykę, sztywno obramowaną innym zakresem możliwego doświadczenia. 


\section{Teatralizacja, metaforyzacja i zmiana biegu życia}

Wśród praktyk psychoterapeutycznych znana jest troska o ułatwianie reprezentacji bólu i cierpienia - aż po traumy i dramatyczny impas egzystencjalny - przez narracje, symbolizacje i formy zastępcze pozwalające na przepracowanie transformujące doświadczenia inaczej nie do zniesienia. Marc Durand i Deli Salini (2018) przedstawili uogólnione wnioski z praktyki „Teatru Przeżycia” (Théâtre du Vécu) skupionego na doświadczeniu afektywnym jego uczestników. Pojawiają się różne „modalności reprezentacji”, uwikłane w tryb przedstawienia, którego scenariusz i narracja powstają z udziałem podmiotu, w stronę którego adresowana jest próba transformacji biegu jego życia. Wystawianie na scenie realności tego, co minione, ale co ciąży, staje się sposobem na transformację umożliwiającą „rozładowanie” napięć i odblokowanie zdolności do życia, inaczej pozostaje uszkodzoną. Uprzedmiotowienia tego, co podmiotowo nie da się bez dystansu gry teatralnej wytrzymać, stają się sposobem przezwyciężenia ciężaru „uobecnienia” (présentification) tego, co się wydarzyło w życiu. Produkcja sceniczna z wykorzystaniem technik teatralnych i z pomocą aktorów otwiera się na „polisemię, niuanse i subtelności interpretacyjne", z powstawaniem przestrzeni naprzemiennej perspektyw aktora i widza, w procesie rozplątywania znaczeń i poszukiwania ich rekontekstualizacji, gdy transformacja zorientowana jest ostatecznie na zmianę znaczeń w trybie opracowań i przetworzeń teatralnych, aż po użycie środków dekonstruujących w sploty wcześniej niewłączane do rozważań i przeżyć. Może to, jak się okazuje, istotnie rzutować na dalszy bieg egzystencji tego, kto takiemu przeorganizowaniu treści i znaczenia doświadczeń da szansę w dynamice teatralizacji. Nie ma tu linearności, a raczej chodzi o „cyrkularność” wzajemnych odniesień, otwierających dostęp do nowych możliwości rozumienia wydarzeń w ich bardziej uogólnionej i przesuniętej emocjonalnie perspektywie, uwzględniającej różne aspekty przetworzeń w postaci nakładających się na siebie „modalności zaangażowań”: świadka wydarzeń, interpretatora doświadczenia, autora tekstu stanowiącego narrację, inscenizatora proponującego rozwiązania w grze, przyjmującego także pozycję widza, czy wreszcie praktyka podejmującego nowe dla siebie zadania teatralne i oswajającego się z nowymi dla siebie technikami ekspresji i aranżacji. Wszystko to wzbogaca nakładającymi się perspektywami percepcji wyjściowej sytuacji o dystans niosący szansę transformacji doświadczenia, najpierw jednorodnego do bólu. Okazuje się możliwa „metaforyzacja doświadczenia” dająca w pewnym stopniu zerwanie wcześniej nienaruszalnej więzi (détachement) z tym, co boleśnie przeżyte, choć znaczenie/znaczone w jego trzonie pozostaje (inaczej) znaczące i respektowane, a nawet współprzeżywane i podzielane (partagé) w szerszej perspektywie interpretacji. Jest ona bogatsza o zwielokrotnienie profili/biegunów zaangażowania $\mathrm{w}$ postawie osoby wymagającej transformacji egzystencjalnej. Inscenizacja staje się ekranizacją reprezentacji splecionych między sobą (entremêlées), obejmujących różne odnie- 
sienia do emocji, przeżyć twórczych i rozterek w interakcji ze współuczestnikami przedstawienia zmieniającego stosunek do życia. Odgrywanie burz psychicznych pozwala je przezwyciężać $w$ ich realnym wymiarze jako dające dostęp estetyczny do „doświadczania doświadczenia”, pozwalając na przeżycie transcendencji rozwijającej jej uczestników. Jednostka zmienia tym samym sposób własnej „indywiduacji” jako głębszego odnoszenia się do siebie samej i własnych stanów tożsamościowych z zapośredniczeniem ich przetworzeń artystycznych na scenie $\mathrm{w}$ dwubiegunowym uwikłaniu perspektywy jednostki i impulsów ze strony zespołu współuczestniczącego w odgrywaniu stanów boleśnie wcześniej przeżytych. Transformacja polega zatem także na zmianie ekologii odniesień na ja-w-relacji trans indywidualnej, osłabiającej grą między fikcją sceniczną i realnością groźne emocjonalne skutki doświadczenia wcześniej wręcz paraliżującego jakość życia. Autorzy rozważań korzystają m.in. z odniesień do pragmatyzmu Deweya w jego edukacyjnych ujęciach doświadczenia, jak też włączają metaforykę mitów greckich, co tu muszę pominąć.

\section{Transformacje pracy zależne od wiedzy}

W ujęciu trzech Brazylijczyków (Charles Cuhna, Geraldo Santos, Daisy Cunha 2018) kontekst rozważań stanowią doświadczenia w górnictwie (katastrofy w sektorze wydobywczym). W ramach tego odniesienia podejście autorów uwypukla złożoność relacji wpisanych w kontinuum zróżnicowania wymiany perspektyw między badaczami i badanymi górnikami. Ukierunkowanie dążeń określają mianem „pedagogiki aktywności ludzkiej” z udziałem kształcenia w ramach uczelni i różnych kierunków studiów oraz działań związków zawodowych w kopalniach dla uzyskania transformacji sposobów uzyskiwania wiedzy o pracy tam mającej miejsce. W grę wchodziła „spiralna dynamika spotkań” otwartych na relacjonowane doświadczenia ich uczestników w trybie rozmów, a nie wywiadów, zwykle przecenianych jako środek dotarcia do warstwy słownej perspektywy rozmówców. Chodziło tymczasem o „krążenie wiedzy i wartości” w dialogu zorientowanym na uwspólnione budowanie (partagée) wiedzy w trybie ciągle na nowo uzgadnianych zakresów spraw do refleksji, w tym ewentualnych transformacji, jak: ryzyko zdrowotne w pracy, prawo do emerytury, funkcjonowanie nadzoru, intensywność pracy, zwolnienia, bezrobocie, jakość zarządzania procesami pracy i całym sektorem - wszystko jako „motywy generacyjne” dla powstawania nowej wiedzy. Metoda „wzajemnych interpelacji” stała się podstawą wyłaniania się nowych wyzwań poznawczych w kłopotliwej dynamice poszukiwania wzajemnego zrozumienia i rezerw zmiany (alternatyw). Trudności powstawały wobec zjawisk wyzysku górników i przy rozbieżnościach lokalnych oraz ignorancji w stosunku do złożoności kontekstów i wcześniejszych doświadczeń, gubionych z pola widzenia. Partnerski dialog wymagał wzajemnego testowania, uczenia się i interpelacji między 
samymi górnikami czy osobami z różnych poziomów zarządzania, gdy odmienne horyzonty rozumienia wpisane są zwykle $w$ odmienne narracje, np. inżynierów i zwykłych operatorów. Dodatkowe trudności rozumienia i tworzenia perspektywy możliwych transformacji wyznaczały próby dialogu górników i badaczy, wymagając wzajemnego uczenia się w partnerskim spotkaniu bez apriorycznej wyższości czyjejś perspektywy czy pozycji, zawsze podległych konieczności zmian (dostosowań „dialektycznych”), przezwyciężających bariery sięgające aż na poziom innych wizji życia. Uczenie się wymagało dopełniania współpracy w „podwójnym kierunku badań i akcji”, tworząc nowe możliwości dla obu zakresów: myślenia i praktyki zawodowej, które jednak nie są przedzielone zwyczajowo widzianą przepaścią czy przerwą, nie ma między nimi „cięcia epistemologicznego” (coupure). Sama transmisja doświadczenia bywa powiązana z trudnościami przezwyciężanymi w jej trakcie, co stanowi nowy typ (poziom) uzyskiwanej wiedzy i zmienia perspektywę epistemologiczną na krzyżującą się z pierwotną, wnosząc zarazem nowe wymiary uwikłań i sprzężeń. Transformację procesu zatem wyznaczają często komplikacje jego przebiegu wymagające uwzględnienia w reprezentacji źródeł i sposobów korekty także jakoś diagnozowanych okoliczności rzutujących na proces spoza ingerencji podmiotu sprawującego nad nim funkcje koordynatora. Nakładają się tu na siebie „trzy bieguny” odniesień do wiedzy, wpisane w ramy działającego mechanizmu (dispositif): dziedzictwa dyscyplin wchodzących w grę, zakresu ucieleśnienia wiedzy $\mathrm{w}$ doświadczeniu podmiotów uczestniczących w procesie oraz nastawień społecznych, poznawczych i wartościujących, leżących u podstaw zespolonego dążenia do wytworzenia nowej wiedzy w procesie pracy. Autorzy widzą tu „continuum aktywności" w różnych przepływach percepcji kwestii wchodzących tu w grę oraz $\mathrm{w}$ przekrojach przestrzeni powstających na tych biegunach. Odniesienie do „continuum naszych wymian” powraca jeszcze w tekście tematów generowanych do roztrząsania jako ważnych, choć wymagających uznania. Wśród wymiarów praktyki wyróżnia się działalność dialogiczna jako typ komunikacji niezbędnej dla budowania wspólnoty podzielającej słownik, znaczenia pojęć, rozumienie sytuacji i powstających nowych więzi jako podstawy współpracy w zakresie wytwarzania nowej wiedzy. Ma to służyć nowemu „upełnomocnieniu” (empowerment) podmiotów w zakresie inicjowania i przeprowadzania zmiany swoich potencjałów działania, warunków pracy i życia. Zwrot ten zresztą powraca w tekście, jako że dotyczy wzmacniania tożsamości, mocy działania i zdolności rozpoznawania „rezerw dla alternatyw w środowisku" pozornie nie do zmiany. Zawsze w grę tu wchodzi zjawisko szukania impulsów do nowego zarządzania i uzyskiwania wiedzy, uwzględniając „przebiegające tymczasowo napięcia w równoważeniu (l'equilibrium) współpracy badaczy i górników". Podstawą jednak jest nie tyle oparcie wiedzy na wywiadach, ile na nadaniu poprzez dialog słowu uczestników pracy centralnego znaczenia $\mathrm{w}$ procesie rozumienia złożoności procesu pracy i jego skaz. Słowo to problematyzuje pole rozważań, uruchamiając w nim „motywy generujące” badania, znaczenia i postulaty zmiany, co autorzy rozdziału przytaczają za słynnym brazy- 
lijskim pedagogiem krytycznym Paulo Freirem (1972) i jego „pedagogiką (dla) uciśnionych" (por. Kostyło 2011). W niej, jak wiadomo, od uznania strukturyzującej i symbolicznej wartości słowa (Word) zależy respektowanie prawdy krytycznego świadectwa o generującym je świecie (World). Chodzi w szczególności o uznanie „szkodliwych aspektów środowiska pracy”, stanowiących źródło opresji. Jako niezbędne jawi się tu podejmowanie wysiłku edukacji kształtującej zdolność podejmowania kwestii krytycznych, z uwzględnieniem wiedzy i wartości wdrażanych do krążenia w słownikach poszczególnych podmiotów pracy, uzyskujących w ten sposób nowe zasoby tożsamości i uznanej podmiotowości, umiejącej upominać się o siebie, w tym o poszanowanie siebie. Otwiera to pole do domagania się zasadniczych nawet transformacji procesów pracy, wcześniej odbieranych jako nieuchronne. W centrum uwagi stają dla przykładu problemy bezpieczeństwa pracy w obliczu katastrof czy wypadków, które zwykle zbyt powierzchownie bierze się pod uwagę $\mathrm{w}$ oficjalnych reprezentacjach warunków pracy jako generujących nawet dramatyczne przesłanki dla transformacji. Blokowanie wprowadzania zmian instytucjonalnych w zarządzaniu pracą może wywoływać ukryty opór podmiotów procesu pracy $\mathrm{w}$ postaci zachowań spoza kontrolowanych $\mathrm{w}$ trybie organizacji pracy, np. przez osłabianie zaangażowania i tempa pracy, spowalnianie, robienie przerw, co może jednak pojawiać się w kolizji z interesami innych pracowników. Pojawia się kwestia języka, którym takie zachowania będzie się określało w przestrzeni pracy i szukało źródeł powstających napięć i sprzeczności z ewentualnością transformacji samego procesu pracy i współdziałania w jego ramach aktorów, zarządców i różnych aspektów interesów w procesie uczestniczących. Ważne wreszcie okazuje się dostrzeganie „krzyżujących się zakresów” (tessitures entrecroisées) badań i interwencji w badane sfery pracy, zarazem wskazujących konieczność rozwiązań ekonomiczno-prawnych spoza wąsko pojmowanej pracy i otwarcia w zarządzaniu życiem społecznym i jego „rezerwami alternatyw” jeszcze niewykorzystanych. Warunkiem transformacji, niezwykle trudnej do przeprowadzenia, jest ustanowienie nowych powiązań $\mathrm{z}$ innymi podmiotami sceny pracy $\mathrm{w}$ innych zakresach profesjonalności w bardziej holistycznym ujęciu, nie wyłączając kwestii sprawiedliwości społecznej. Produkcja wiedzy nie wystarczy dla transformacji, jeśli nie będzie szła w parze z jej uświadamianiem sobie (przejęciem i przetwarzaniem) i odnową w podejmowaniu i rozwiązywaniu problemów, w których odniesienie do pracy w kopalniach wymaga także odniesienia do jakości życia we wzajemnym sprzężeniu tych dwóch biegunów jednej całości społecznej.

\section{Cielesność jako reprezentacja i medium transformacyjne}

W kolejnym ważnym tekście, autorstwa Martine Dutoit (2018), miejscami chyba nazbyt skrótowym, mamy świadectwo niezwykłych wyzwań dla profesjonalnej interwencji medyczno-społecznej na etapie wczesnym (précoce) rozwoju wobec 
dzieci o szczególnej niepełnosprawności - niewydających dźwięków, niemówiących, a nawet „zanurzonych we własnych ciałach”. To może oznaczać także przejawy autyzmu, skoro zadaniem dla profesjonalistów jest to, aby do nich dotrzeć i nawiązać komunikację poprzez kontakt wykorzystujący gesty pozyskujące interakcję i wzajemną reprezentację bez słów. Profesjonaliści mają dalej zadanie nie tylko wyrazić i uzgodnić między sobą swoje rozumienie obserwowanych zachowań jako interakcji, ale muszą oprzeć swoją reprezentację stanów i konstruowanie interwencji na wspólnym holistycznym założeniu. Tym oto, że interakcja z niemym, zamkniętym w sobie małym interlokutorem dziecięcym wymaga skupienia się na „grze ucieleśnionego systemu interpretacji”, bo to ciało się uczy i poprzez ciało dziecko się uczy, odbiera siebie i świat. Dziecięce zasoby emocjonalne, poznawcze, komunikacyjne i rezerwy do zmobilizowania na rzecz jego transformacji, a tym bardziej rozwoju także są dostępne jedynie poprzez gesty cieleśnie konstruowane, choć wymagające dalej głębokiego rozumienia i włączenia w próby komunikowania się profesjonalnych terapeutów z dzieckiem na nowe sposoby, poprzez spotkanie sensoryczne, uruchamiające zmysły. Ciało dziecka mówi i odbiera, i trzeba to umieć dekodować, ale też projektować. Zanurzenie w cielesnym bycie nie może stanowić bariery nie do pokonania, aby otwarła się droga na zewnątrz z zamknięcia, nieufności, jak i do wewnątrz do zanurzenia się grą dotyku w innym świecie dziecka, inaczej niedostępnym. W tekście powraca wielokrotnie metafora bycia „zanurzonym" (plongée) oraz metafora pojemnika (contenant), gdyż wokół nich organizuje się zadanie konstruowania relacji, szukania dostępu, odzyskiwania kontaktu i podejmowania prób przeorganizowania percepcji na rzecz uruchamiania potencjału transformacji. Jest to konieczne pomimo trudnych do rozpoznania i przezwyciężania kolejnych blokad psychologicznych, psychomotorycznych oraz kinetyki interakcyjnej ze światem z uwzględnianiem kolejnych potencjałów rezonansu czy „fluktuacji wewnętrznych tonalności”, jak czytamy. Nie ma innego sposobu przerzucania pomostów między działaniem cielesnym oraz komunikacją symboliczną z obu stron relacji o dramatycznie uszkodzonych obu członach reprezentacji i transformacji: dziecko versus profesjonalista. Wymagany jest tu trudny proces wzajemnego dostosowania, dopasowania (ajustements). Inaczej uczestnicy tych prób nie zdołają wyjść ze swoich ram, które w przypadku dziecka poprzez jego ciało tworzą jego schronienie pozwalające na ucieczkę, wycofanie w ograniczenia, po stronie profesjonalisty znaczyłyby skalę jego bezradności. Szanse na profesjonalne uruchamianie transformacji adresowanej wobec dziecka rosną wraz z wysiłkiem uzgadniania między kilkoma specjalistami (w tekście mowa o trzech zakresach interwencji) charakteru reprezentacji doświadczanych, a zakodowanych cieleśnie impulsów oraz uruchamiania transformacji w postawach samych tych profesjonalistów. 


\section{Implikacje reprezentacji/transformacji w kontekście tańca}

Działania rozumiane jako „kroki do podjęcia” czy „przejścia między krokami”, zarówno w sensie dynamiki ruchu, jak i opisu sugerowanych działań, wymagają znalezienia stosownej perspektywy uczenia, realnej praktyki i troski o jej odbiór przez obserwatorów (np. estetyzacje) w szerszych ramach działania niż tylko ekspresja taneczna jako ilustracja ruchu ogólniejszego. W tekście Nicole Harbonnier (2018) z Montrealu spotykamy uwypuklenie dwóch podejść konceptualizujących podejście do postulowanego opisu przerzucającego „pomost między myśleniem i działaniem", co zresztą daje o sobie znać nie tylko w kontekście ruchu tanecznego. Teoretycy i praktycy tego ostatniego jednak wskazują bądź to na (1) ujęcie w przekrojach różnych wymiarów w modelu „continuum między biegunami” (polarités), który pozwala na typologizowanie postaw i nazywanie różnych stanów ruchu, bądź też na (2) typy postulowanych działań z wykorzystaniem reprezentacji odniesionych do "gry między biegunami” obecnymi w ruchu, gdzie kluczowe są uwarunkowania dynamiki „modulowania stanu ciała”, ze względu na relacje między składowymi psychodynamicznymi (composantes), obejmujące napięcia, fluktuacje, ale także „alternacje między napięciem i relaksacją”, w kontekście innych uwarunkowań, z wykorzystaniem dialogu między stosowanymi technikami i przywoływanymi, wyzwalanymi emocjami. Ogólniejszy potencjał rozumienia transformacji w działaniu profesjonalnym daje się wyrazić, jak się okazuje, przez aspekty tego działania określane w tekście jako: (a) dyspozycja do nastawienia się na optymalność działania (se disposer), (b) rozumiejące usytuowanie się w realiach tego, co się wydarza (se situer), (c) znalezienie się we właściwej pozycji co do czasu, miejsca i możliwości (se positionner), a także (d) znaczące dla siebie przekształcenia się podmiotu działania jako osoby (se transformer). Transformacje więc jawią się ostatecznie jako sprzężone z szeregiem uwarunkowań i zależności w „zapętleniu" (en boucle) działania i jego postrzegania oraz podejścia do niego przez podmioty w działanie uwikłane. Transformacje mogą także różnić się stopniem ich stabilizacji, a zatem również jakością wystabilizowania ich reprezentacji (konceptualizacji). Dla jednych rozrzut stanów na kontinuum spolaryzowanych biegunów wystarczy, ale dla innych jest to wysoce niewystarczające. Decyzje dotyczące modulacji dynamiki działania i przebiegu procesów nie dają się redukować do wyboru jednego z palety stanów, a tym bardziej do zajęcia jednego z przeciwstawianych sobie wariantów biegunowych.

\section{Instalacje jako ograniczenia transformacji}

Londyński badacz Saadi Lahlou (2018) omówił badania posługujące się „teorią instalacji", wskazując, że taka reprezentacja mechanizmu regulacji aktywności instytucji społecznych i podmiotów z nimi związanych w istocie znacznie ogranicza możliwość uruchamiania $\mathrm{w}$ tym wymiarze praktyki profesjonalnej zasadniczych 
transformacji. Ramy instalacji społecznych dopuszczają margines sytuacyjnych, indywidualnych odstępstw i transgresji od trwałych mechanizmów regulacyjnych, jednak nie w sposób psujący przewidywalność i naruszający zasadniczy proceduralny charakter funkcjonowania konkretnych rozwiązań instytucjonalnych jako efektów praktyki społecznej przynoszącej takie jej przejawy. Służą one zasadniczo reprodukcji trajektorii działań niezależnie od tego, czy instalacje społeczne uczestniczą w wielokrotnie powracających tzw. „repizodach” wpisanych w powtarzane doświadczenie, czy też wiążą się z pojedynczymi epizodami w cyklu życia, zmuszając człowieka do jednokrotnych lub przypadkowych kontaktów z daną instytucją i jej urządzeniami. W praktykę funkcjonowania instalacji, podkreśla badacz, są wpisane momenty „bifurkacji” jako rozdwojeń możliwych zachowań, dopuszczanych proceduralnie, determinowanych jednak przez wyraźnie określone czynniki, wpisane w kolejne fazy przebiegu aktywności sprzężonej z udziałem adresata. Stałość rekonstrukcji sytuacyjnych w ponawianych działaniach instytucji dopuszczają w tej perspektywie jedynie stopniowe modyfikowanie instalacji ze względu na ich efektywność i kontrolę stanu, radzenia sobie z wyzwaniami. Takie obramowanie działania ma dostarczać teoretycznej „wartości dodanej” głównie w przypadku bardziej złożonych praktyk społecznych, ograniczających momenty dowolności działania, w tym usuwających groźbę niedopuszczalnych naruszeń reguł działania przewidzianych dla danej instalacji (np. recepcji dla chorych zgłaszających się do przychodni). Wielokrotnie powraca w pracy wskazanie na „affordancje” instalacyjne jako wyraz możliwości wpisanych dla działania jednostek w ich uwarunkowania środowiskowe, gdy podejmują kontakt z daną instytucją społeczną. Wpisane są one w trzy warstwy przejawiania się instalacji i ich niezwykłego (assez étrange) „statusu epistemologicznego" jako obejmującego jednoczesne dopełnianie się odniesień do fizycznie dostępnego miejsca praktyki i jego aranżacji, do dyspozycji, jakie się z nim wiążą z wymogami wobec nastawień pracowników wobec klientów, oraz reguł, jakie wyznaczają tryb jego procedowania, określając role społeczne jako uogólnione oczekiwania. Warto by jednak podkreślać dodatkowo możliwość napięć, a nawet sprzeczności między poszczególnymi instalacjami, co dobrze ilustruje zderzenie instalacji wprowadzonych dla traktowania pacjentów covidowych w obecnej pandemii z wcześniejszym funkcjonowaniem szpitali z ich dostępem dla osób zgłaszających się z innymi schorzeniami. Nie wystarczy więc powiedzieć, że instalacje mają „podwójną funkcję umożliwiania i regulowania”, gdy należy dostrzegać groźbę nie tylko zderzeń i sprzeczności w sytuacji narastania złożoności otoczenia, w jakim działają, a także, gdy dostrzeże się dwoistość strukturalną wewnętrznego napięcia par funkcji (umożliwiania versus wykluczania oraz regulowania versus blokowania). Pojęcie instalacji społecznej jako ramy dla reprezentowania instytucji i jakości ich funkcjonowania i transformacji wymagać się zdaje bardziej złożonego opisu strukturalnego, choć wystarczająco już anonsuje swoją przydatność. 


\section{Przedmioty techniczne jako medium upodmiotowienia}

Na przykładzie aparatu fotograficznego czy turbin - ale też szerzej: przeciwstawienia konkretności i abstrakcji urządzeń - kolejna para badaczy z uczelni brazylijskiej (Lucilia Machado, Antonio Tomasi 2018) śledzi w wybranych kontekstach teoretycznych procesy transformacji podmiotowości, których nie da się postrzegać bez uwikłania w przyswojenia i oswojenia (appropriation) obiektów technicznych dla wyrażania siebie i pogłębiania relacji ze światem. Owo upodmiotowienie (subjectivation) - czasem tłumaczone jako subjektywacja, w duchu Michela Foucault - musi uwzględniać przeobrażenia w środowisku człowieka i w jego interakcjach społecznych także poprzez wymiar techniczny. Kluczowy bowiem w działaniu profesjonalnym jest zawsze realizowany ze wsparciem technicznym motyw (niemylony z przyczyną), wyrażający się nastawieniem kulturowym podejmującego je wobec środowiska, a nie tylko operacją skoncentrowaną na narzędziu. Termin „motyw” wielokrotnie powracający w tekście odsyła do uprzedmiotowienia potrzeb, jakie przyświecają aktywności lub kierują danym działaniem. Mediacja poprzez przedmioty techniczne staje się sposobem wyrażania podmiotowości, jest uwikłana zarazem w skrajności między technofilią i technofobią, czytamy, co oznacza dominującą skłonność do postrzegania zapośredniczeń technicznych w ramach tzw. „logiki manichejskiej” rozłączającej dobre i złe strony techniki, w tym zagrożeń płynących $\mathrm{z}$ dominacji wymagań, jakie środki techniczne stawiają człowiekowi, choć można je także sprzęgać z realizacją wartości, uzyskiwaniem wiedzy i postrzeganiem sensu. Daje się rozpatrywać „stopnie techniczności”, różnice w statusie obiektów technicznych i skali alienacji, jaką mogą wywoływać, czy automatyzmów, jakich zakładnikami mogą czynić podmioty sprzęgające z nimi swoje działania. Inne też są możliwości transformacji relacji: człowiek versus maszyna, w systemie otwartym na impulsy zewnętrzne, aż po zerwania (ruptures) i działanie indeterminacji, bez zamknięcia w sztywnej przewidywalności. W powiązaniu wzajemnym człowieka i techniki powstaje nowa przestrzeń rozwoju podmiotowości działającej, zdolnej rozpoznawać i tworzyć nowe potencjały „upodmiotowienia" poprzez mediację techniczną generującą nowe przejawy reprezentacji w środowisku życia. Daje tu o sobie znać zjawisko „transdukcji” jako takiego sprzęgania przeciwstawnych elementów, które w tej integracji zarazem uzyskują wyższy stopień zdolności pogłębiania swojej indywidualnej złożoności i nowej jakości efektów z tą integracją związanych. W grę wchodzi także zdolność uczenia się wzajemnie od siebie, jak i dzięki sobie, co tworzy nowy charakter kultury technicznej i ludzkiej zarazem, uwolniony od siły determinacji automatyzmów po obu stronach tak ontologicznie sprzężonej relacji. 


\section{Kwestia niewidzialności i milczącego charakteru transformacji}

W jedynym tekście reprezentującym polską myśl pedagogiczną Ewa Marynowicz-Hetka (2018) przywołuje ustalenia wpisane w teoretyczne rozważania wokół podstaw pracy socjalnej widzianych $\mathrm{w}$ ramach tradycji pedagogiki społecznej. Empiryczne odniesienia wiążą się z badaniami sposobów charakteryzowania postaw asystentów rodziny oraz relacji w szkołach jak i ujmowania możliwości ich zmiany. Autorka upomina się o dojrzałą perspektywę epistemologiczną dla problematyzowania transformacji w sferze aktywności profesjonalnych. Postulaty obejmują akcenty paradygmatyczne uwolnione od pozytywizmu, a zorientowane z kolei na podejście sprzęgające perspektywy interpretacyjne, holistyczne, transwersalne, uwypuklające dynamiczne procesy, a nie stabilizowane stany. Chodzi o wypracowanie podejścia uwzględniającego zjawiska sprzężeń i relacyjności, płynności zjawisk. Uwagę zwraca się na diachroniczność krótkoterminową biograficznie jak i długoterminową historycznie. Oparciem dla postulowanej perspektywy jest odniesienie do kultury, zarówno w sensie „kultury praktyki”, jak i wymiaru symbolicznego w aktywności i nastawień nieuświadamianych. Analizy nawiązują do narzędzi uwypuklających wagę zjawisk niedostrzeganych, choć obecnych poza sferą intencjonalności, a nawet pozbawionych dyskursu (milczących) i postrzeżeń (niewidzialnych), a mimo to istotnych dla jakości praktyki profesjonalnej, mimo że ukrytych także poza świadomością aktorów (uczestników). Za Deweyem powraca waga troski o „doświadczenia uwspólnione” (expériences partagées) jako podstawę wspólnot warunkujących współdziałanie w relacji; zmiany w praktyce są uwypuklane także w kategoriach zerwań, spirali i splotów. Ważne okazują się aspekty mediacyjne i cechy rozpoznawane jako paradoksalne, np. w zakresie efektów specyficznych transformacji niewidzialnych, wymagających relacji nie tylko ukierunkowanych i w pełni poddanych kontroli, ale wraz z adresatami, poprzez nich i na ich rzecz, ale z uwzględnianiem ich niegotowości, oporów i przeszkód. Kluczowe okazuje się zerwanie z nastawieniem wyznaczającym bariery między teoretycznością wiedzy, praktycznością podejścia i refleksyjnością zaangażowania uczestników. Osobiście sprawia mi satysfakcję akcent explicite na postrzeganie złożoności w kategoriach relacji versus (wobec) jako podstawowej dla rozumienia sprzężeń przynajmniej dwubiegunowych, dwoistych w ich naturze.

\section{„Gesty techniczne” $\mathrm{i}$ ich przemiany}

Dwa kolejne teksty autorstwa André Guillerme (2018) i Marka Bombaire’a (2018) zawierają odniesienie do tytułowej kategorii tego fragmentu relacji: „gesty techniczne" zarówno w kategoriach historycznych, jak i charakteru ich wpływu i źródeł przeobrażeń. Interesująco wygląda historia dojrzewania w wieku XVIII uznania dla konieczności wprowadzenia do nauczania kursów $\mathrm{z}$ „technologii” jako nauki 
stosowanej wobec techniki. Wskazane jest przez autorów cywilizacyjne przechylanie się społeczeństwa zachodniego w stronę realiów przemysłowych, przeobrażających sposoby wytwarzania, kontrolowania, przewidywania, kalkulowania zjawisk mających nową skalę i wymagających nowej organizacji aktywności i innej przestrzeni pracy. Technika jest pojmowana jako „społeczny mediator nauki oraz ekonomiczny mediator przemysłu", co przekłada się na wprowadzanie nauczania chemii i mechaniki w kształceniu zawodowym we Francji jako nowego oparcia dla „manufaktur” stanowiących o przyszłości. Pojawiają się nowe postaci publikacji kompendiów wiedzy, jak słowniki i encyklopedie, czasopisma, przewodniki i podręczniki, zbierające wiedzę jako przydatną podstawę „nowej kultury”, nie tylko dla elit, nadającą rangę zabiegom oświeceniowym (kształceniu obejmującemu dorosłych) także w sferze jakości aktywności ludzkiej, jej rozumienia i doceniania. Pojawia się potrzeba „sterylnego" podejścia do wiedzy, czytamy, afirmującego „akademizm” wspomagający narastającą dzięki środkom technicznym industrializację poprzez docenianie „interesu mechanicznego” wspomagania działania w procesach pracy wytwórczej i inżynieryjnej. Pojawia się waga inżynierskiego przekładania na technikę gestów, ruchów ciała ludzkiego, dla pokonania jego ograniczeń poprzez powiązanie mechanizmów w „łańcuchy” działań (enchaînement) o nowej jakości, uruchamiając podejście możliwie najbardziej ergonomiczne. Kształcenie inżynierskie staje się nowym stylem organizacji nauczania jako efekt indukowany przez potrzeby przemysłowe nowej formy i skali produkcji z wykorzystaniem możliwości nowego napędu urządzeń (motorowych), co ustanawia wręcz przepaść między minionym a „nowymi elitami technologicznymi” działającymi w horyzoncie nowych zawodów, wcześniej niemożliwych, a stających się naturalnymi i koniecznymi. Podkreślone jest zarazem narastanie oporu, a nawet upadku tradycyjnych zawodów wobec chemii i mechanizacji, uwypukla się także wagę kapitału czy zjawisk zanieczyszczeń. Pojawia się „druga industrializacja”, ukierunkowana na gigantyczność, higienę, elektryczność, ekonomiczność produkcji. „Gest techniczny” uzyskuje nową jakość i nowe reprezentacje. Ta droga transformacji wiąże się wręcz z rangą „rewolucji przemysłowych” powodujących znikanie całych zawodów. Zmiany historyczne opisane są poprzez zanik wcześniejszej techniki „wybijania monet” i jej organizacji, a także zmiany w zakresie przyuczania zawodowego, a nawet reprezentowania atrybutów i statusu władzy. Prawo bicia pieniądza stanowiło bowiem wcześniej „potwierdzenie suwerenności władzy”, np. książąt, a zawód wybijającego monety (monnayeur) doceniany wcześniej pojawiał się nawet na witrażach, a zarazem był sprzęgany w łańcuchy działań mających chronić przed fałszerzami. Z czasem ta symboliczna reprezentacja wagi bicia monet znika jako pozbawiona odniesienia w praktyce społecznej, wymagając zastąpienia „nowym duchem” inżynieryjnym. Eliminuje to podniosłość nawet ślubowań w cechu wytwórców monet jako symbolicznej reprezentacji ich znaczenia, które zastąpione zostały przez rangę anonimową mennic mechanicznych. 


\section{Przejścia przez poziomy (style) profesjonalne aktywności}

Brazylijski autor Enio Rodrigues da Silva (2018) podejmuje analizy przykładu działań psychiatrii w jego kraju w zakresie różnic uwypuklonych w trakcie prób reformy systemu „azylu” psychiatrycznego między podejściem, jak to określa, włoskim i francuskim, aż po rozwiązania szkoły Lacana. Zderzenie tych perspektyw, jak twierdzi, pozwala na „deneutralizację” wdrożonych wcześniej rozwiązań jako niesprowadzających się jedynie do strony technicznej działania, ale uwikłanych $w$ rozmaite rozstrzygnięcia $w$ kategoriach społecznych i politycznych o charakterze strategicznym. Działanie systemowe całego sektora profesji może być postrzegane jako uwikłane w podejście tradycyjne, wygodne dla przyjętych rozwiązań, wymagając zarazem z innej perspektywy zasadniczej zmiany w stronę uregulowań bardziej humanitarnych w zakresie także funkcjonowania szpitali psychiatrycznych. Wdrożenie normalności" w tej przestrzeni pracy wielorako wyprofilowanej profesjonalnie (multiprofessionnelle) wymagać ma rozwiązań znoszących „pozycję ośrodkową” wiedzy i władzy, jaką przypisuje się w hegemonicznym podejściu „tradycyjnym”, czytamy, traktowania cierpień psychicznych. Chodzi w szczególności o zerwanie (rupture) z praktyką wykluczania takich chorych i przemilczania na przestrzeni historii tego rozwiązania jako normy. Ponad 30 lat poszukiwania i prób wdrażania rozwiązań wobec wcześniejszej dominującej praktyki azylacyjnej (głównie zamkniętych ośrodków psychiatrycznych), autor wskazuje na inspiracje włoskie i francuskie dla tej transformacji. Różnice, jak się okazuje, dotyczyły relacji między biegunami nastawienia: kliniczne versus polityczne z możliwością dominowania radykalności z jednej czy z drugiej strony. Wybrane podejście francuskie promowało „nowy sposób pracy” w profesjach psychiatrycznych, wykraczający poza dominację metod zamknięcia (wykluczeń) reprezentowanych przez instytucje hospicjów, azylów czy szpitali psychiatrycznych, traktowanych z nowej perspektywy jako zbyt totalizujące w swoim formalizmie i hierarchiczności, gubiące zarazem niezwykłość (singularité) sytuacji zarówno pacjentów, jak i profesjonalnego personelu oraz relacji między nimi. Trudno tu w szczegółach omawiać okoliczności tej zmiany poza stwierdzeniem, że ta transformacja tego sektora profesjonalnego była możliwa po zaistnieniu szerokiego ruchu nacisku politycznego, wręcz walki społecznej o reformę trybu funkcjonowania instytucji psychiatrycznych. Kierunek postulowany obejmował podejście zintegrowane, zdecentralizowane, interdyscyplinarne, głębiej zaangażowane klinicznie, psychospołeczne przeciw złemu traktowaniu pacjentów, na rzecz rozwiązania określanego jako „klinika pracy”, integrującego horyzont aktywności na nowym poziomie złożoności, w tym rozumienia złożoności poszczególnych przypadków poza wystarczalnością interwencji farmakologicznej lekceważącej wagę uwarunkowań pozabiologicznych, wymagających poruszania się po szerokim polu kontekstów. Terapia wymaga wówczas reprezentacji „przypadku klinicznego” poprzez reprezentację jego indywidualnego charakteru w trybie organizującym wielopostaciowe 
oddziaływania. Autor omawia jeden z przypadków wymagający rozstrzygnięcia dylematu dotyczącego nastawienia do pacjentki, wiążącego się z kwestią, czy ma się do czynienia z zamaskowanym i wymagającym dekodowania symptomem, jak rozumiem formułę l'acting-out, czy jedynie z postawą i działaniem dającymi się traktować wprost $\mathrm{w}$ ich logice i znaczeniu. Uwypukla to napięcie wymagające „debaty dialektycznej między rozumieniem i transformowaniem zawodu i pracy”; pracy wykonywanej profesjonalnie $\mathrm{w}$ bardziej złożonych przypadkach, odsłaniających możliwe konflikty między wariantami aktywności profesjonalnej, w tym w kontekście psychiatrycznym - od podejścia ściśle klinicznego poprzez włączające zaangażowanie społecznie także transformujące kondycję osób cierpiących, na wielu polach ich aktywności. W grę więc wchodzi ruch na rzecz reformy, mobilizujący presję społeczną i polityczną, bez której transformacja nie mogłaby się dokonać ani nawet być rozpoznaną jako konieczna. Mamy tu więc zaangażowanie zderzające „dwa procesy ideologiczne”: jeden utrwalony w „ideologii instytucji psychiatrycznej klasycznej, tradycyjnej i biologicznej” i drugi o charakterze antyhospicyjnym, antyizolacyjnym, z rozbudowaniem dramaturgii przestrzeni relacyjnej o charakterze bardziej podmiotowym i interakcyjnym społecznie. Nie eliminując wymiaru klinicznego, wymaga to jednak chociażby zmiany trybu podejmowania decyzji klinicznych, jak podkreśla autor, łącznie z „renormalizacją” relacji: terapeuta versus pacjent zakłóconej przez sztywne traktowanie norm profesjonalizacji zawodu psychiatry we wcześniejszym etosie pracy i funkcjonowania instytucji interwencji psychiatrycznej.

Fascynujący fragment rozważań wprowadza z pewnym dystansem analizy pojęcie „dryblingu (un drible) profesjonalnego” jako stylu interakcji profesjonalnej, mobilizującej „wiedzę z różnych porządków”. Wymaga on techniki zwodzenia w sensie zwodów (débrouiller), zwrotów, uników kojarzonych ze stylem brazylijskiej piłki nożnej słynnym na świecie jako finezyjnej „konfrontacji z tym, co realne”, szukającej rozwiązań z unikaniem konfliktów (zderzeń i fauli) także poprzez przechytrzenie przeciwnika (détournement) nagłą zmianą zamiaru co do kierunku ruchu. Autor sugeruje, że jest to przeniesione do podejścia Brazylijczyków do pracy także $\mathrm{w}$ innych profesjach, a nawet do życia codziennego. Wymaga to postawy bardziej intuicyjnej, a nie wyrozumowanej, tworząc zarówno nową estetykę, niemal tańca, jak i etykę zawodową i społeczną jako „zdolność normalizowania sytuacji codziennych" stosowaną w biegu aktywności, reprezentując spontaniczność kulturową mającą swoje korzenie historyczne w nierównościach, z którymi trzeba było jakoś sobie radzić, nie mając szans w zderzeniu z postawą władzy. Nie chcąc widzieć w tym ujęciu pełnego wyjaśnienia, autor przywołuje jako komplementarną wartość uznania czy respektowania zmysłowości i elastyczności interakcyjnej także w sferze języka, a nawet refleksyjności zawodowej i politycznej. Pozwala to mówić o charakterze nowej „psychodynamiki pracy” z innym, bardziej plastycznym zaangażowaniem ciała i myślenia twórczego w kulturze improwizacji. Dotyczy to więc postawy otwartej na nowe drogi poszukiwania rozwiązań nieznanych, wręcz 
niesłychanych (inédites) dla stabilnej praktyki, operujących kierunkiem sinusoidalnym (sinueuse), bez frontalnych zderzeń z innym, z zachowaniem niezbędnego dystansu pozwalającego na „drybling” profesjonalny w omijaniu przeszkód i agresji. W procesie diagnoz wymaga to większego zakładania konieczności poszerzania debat, na zawsze formułujące jedynie hipotezy, choćby i przeciwstawne, w zakresie interpretacji dostępnych symptomów, dotyczących problemów z więzią, bardziej sytuujące pacjenta z pewną dozą wątpliwości między (entre) biegunami, co autor omawia na przykładach widzianych z perspektywy lacanowskiej wymagającej większej bliskości i dłuższego czasowo przebiegu procesu wyrabiania sobie rozumienia danego przypadku. Łatwość i jednoznaczność prób diagnoz to oznaka braku wnikliwości i ostrożności wobec złożoności „enigmy realnego” i zdarzającej się konieczności „reewaluacji” ramy teoretycznej na wariant uwzględniający także hybrydalność wiedzy, jaka musi dojść do głosu dla pełni przekrojów „psychiatryczno-klinicznych pracy". Mają one pozwalać na zmianę znaczeń przypisywanych zachowaniom pacjentów, z przenoszeniem procesów rozumienia aż na płaszczyznę antypsychiatrycznego kwestionowania obowiązujących norm instytucjonalnych kwalifikacji danych zjawisk. Wiąże się to z zadaniem dopuszczenia bardziej do głosu samego pacjenta w rozmowach wyjaśniających, z większą szansą na powstanie wspólnie podzielanej (partagé) perspektywy interpretacyjnej używania siebie przez pacjenta między nim i innymi uczestnikami procesu. Ceną jest poważniejsza dramaturgia bilateralna w procesach pozwalających na spotkanie mimo wcześniejszej wizji zasadniczego pęknięcia relacji i niedostosowania do zakładanej normatywności, a wiąże się ona z „procesem rekonfiguracji wiedzy ukonstytuowanej” w psychiatrii dla odsłonięcia możliwości dotarcia do nowych znaczeń obserwowanych zjawisk i wymagań aktywności profesjonalnej. Wymaga to, jak twierdzi autor, w nastawieniu profesjonalnym do pracy podejścia o charakterze „restytucji konfliktu” między „realnym” (w sensie Lacana, jak rozumiem) a „realizowanym” w trakcie interwencji. Wymaga zatem koncentracji na sferze obserwowanych przemieszczeń pacjenta, rozumianych jako symptom przechodzący ewolucję umożliwiającą zdrowienie. Tu instytucjonalizowanie konfliktu w aktywności profesjonalnej ma na celu prowokowanie do nowych zachowań i ich renormalizacji poprzez przemieszczenia ich znaczeń metaforycznych i inne zniuansowane aspekty profesjonalnego ich przetwarzania, których tu przywoływać nie sposób poza wskazaniem kierunku na poszukiwanie słownika oraz przemianę mechanizmów w instrumenty opanowywane następnie w aktywności zmieniającej ich funkcję i siłę rażenia. Tym samym zasadą staje się „działać, aby zrozumieć”, uruchamiając kryzysy, które pomogą przezwyciężyć - poprzez zmianę znaczenia - sam kryzys zasadniczy, stanowiący źródło symptomów leżących u podstaw problemu psychiatrycznego danego pacjenta. Kluczowa transformacja wymaga „restytucji klinicznej” kondycji pacjenta jako „bycia-w-świecie” konstytuowanego na wiele sposobów niedających się uwzględniać w tradycyjnym wąskim pojmowaniu interwencji klinicznej. W grę wchodzą „nowe przynależności (adhésions) profesjonalne”, zdolne zderzać 
ze sobą typy zaangażowań i warunki ich realizacji tak ideologiczne, jak i materialne, w nową „dialektykę” relacji w procesie pracy psychiatry i jego instytucji. Znacznie dokładniejsze charakterystyki przynosi rzecz jasna sam tekst tu tylko sygnalizowany, z konieczności.

\section{Analogie w służbie transformacji}

Ostatni tekst książki, autorstwa pracującego w Genewie francuskiego badacza Emmanuela Sandera (2018), przynosi analizy edukacji szkolnej oparte o sprzężenie pochwały osobliwości (singularité) oraz afirmacji podobieństwa (familiarité) w trybie uwzględniania procesów odsłaniania się analogiczności i to dwóch zakresów: analogii w uczniowskich aktywnościach edukacyjnych, opartych na doświadczeniach i pojęciach codziennych oraz tych drugich, obecnych w konstrukcjach w nauczaniu, służących transformacji wiedzy oraz samej tej aktywności pierwszego typu. Przez pryzmat typów podobieństwa ustanawiających całe „kaskady analogii” w konstruowaniu łączących relacji, dynamicznie przezwyciężających różnice autor wskazuje na cztery aspekty analogii. Po pierwsze chodzi o aspekt „kategoryzacji naturalnej” - stanowiący nadużycie typ podejścia sugerujący analogię jako „naturalne" podobieństwo, bez konstrukcyjnej sprawczości podmiotu je wskazującego, a oparte w intuicyjnym kojarzeniu oczywistości przystawania (wersja platońska); można ją osłabiać, posługując się prototypami czy wcześniejszymi odniesieniami, służącymi za podstawę kategoryzacji; dodam, że może tu być roszczenie odrzucające sprawczość, ale nadające rangę takiej kategoryzacji, jak w przypadku „prawa naturalnego", gdzie analogię wyznacza status transcendentny spoza ingerencji ludzkiej, więc pierwotny. Drugi aspekt dotyczy „płynności (fluidité) kategorii mentalnych" - przejścia z udziałem różnych, wręcz rozbieżnych perspektyw, uwypuklających jakieś strony podobieństwa sugerowanego jako bliskie czy ważne pod jakimś względem wyróżnionym dla tego zestawienia, pozwalając na ześlizgiwanie się, osuwanie się (glissements) skojarzeń mniej czy bardziej istotnych albo wręcz arbitralnych; kojarzenie analogii w odniesieniach między sytuacjami życiowymi pozwala na kategoryzacje patrzeć jako na podejścia, których płynność wyraża się „plastycznością” samych tych kategorii. W trzecim aspekcie „abstrakcji” chodzi o zasadną pracę, łączącą wskazywane regularności ponad rozdzielające osobliwości, pod jakimś kątem „artykulacji” pozwalającym na stopniowalne lekceważenie różnicy skądinąd nienegowanej, choć artykulacyjnie nieistotnej dla danego podejścia. Mamy tu więc różne stopnie i kierunki abstrakcji, pozwalające na uwypuklanie płodności pomijania specyfiki jakichś stanów generalizowanych w jeden transcendowany typ, chociaż podobieństwo powierzchowne, zjednoczone metaforą (szukanie klucza jako próba rozwiązania problemu) nie wystarcza, nie niosąc ze sobą przydatnej operacjonalizacji o nowej sile; jednak zdarzają się metafory otwierające 
pole postępu poznawczego, np. „ogólna teoria względności”. Wreszcie aspekt czwarty jest określony jako „projekcyjny”. Tu analogia ma projektować perspektywę nowej, wzbogacającej interpretacji, kojarzącej to znane przez analogię z nieznanym, wykraczającej poza podobieństwa zmysłowe, a pozwalającej podstawić informację projektującą dekodowanie, choć bywa ono oparte o iluzje. Mamy tu zatem nakładanie, narzucanie znaczenia dodatkowego (surajoutée) na stany nierozpoznane, wzbogacając rozumienie środowiska człowieka, także poprzez transformacje posługujące się pamięcią epizodów. Projekcje pozwalają przez ich analogiczny charakter przewidywać czy tylko zakładać przyszłe stany i są nieodłączne od wielu decyzji ludzkich i oczekiwanych efektów podejmowanych działań. Przez to „płodność projekcji” staje się „motorem ewolucyjnym” procesów, dając poczucie zadomowienia w środowisku pełnym aspektów nierozpoznanych, ukrytych, zasłoniętych; tak działają, kierując się analogią jako projekcją treści wcześniejszych doświadczeń.

Po takich ogólnych rozważaniach mamy w tekście odniesienie do sytuacji nauczania - na przykładzie matematyki w edukacji elementarnej - poprzez wskazywanie działania trzech typów analogii stosowanych przez dzieci w trybie skojarzeń z życia codziennego, które często bywają w użyciu ludzi dorosłych jako naiwne operacje poznawcze. Bywają one czasem pomocne, a czasem szkodliwe, w sensie przeszkód epistemologicznych w rozumieniu Bachelarda $(1940,1980,2000)$. Są to analogie (a) substytucji, (b) scenariusza i (c) symulacji. Omówienie ich zajęłoby tu sporo miejsca. Wspomnijmy więc jedynie, że ramą je organizującą są skojarzenia z operacjami matematycznymi: odejmowania z wycofaniem (retirer), dodawania $\mathrm{z}$ dorzucaniem (ajouter), mnożenia z powielaniem (reproduire), a dzielenia z podzielaniem (partager). Analogie substytucji pozbawione są często niezbędnej paradoksalności rozumienia sytuacji dających się kojarzyć inaczej, wręcz przeciwnie niż te analogie dyktują. Scenariusze w analogii oznaczają stosowanie zasady symetryczności sytuacji, gdy tymczasem chodzi o radzenie sobie także z asymetrią bez wymienności członów sytuacji; czasem więc takie analogie ułatwiają, a czasem też utrudniają radzenie sobie ze złożonością sytuacji. Wreszcie analogie symulacyjne dotyczą sytuacji, gdy dzieci wdrażane są do arytmetyki przedszkolnej lub w trybie doświadczenia pozaszkolnego, czyli w życiu codziennym wymagającym kojarzenia, np. cen w kontekstach liczby przedmiotów i manipulacji w trakcie ich zakupów lub przy decyzjach ich dotyczących. Praca przywołuje dla zainteresowanych bogatą literaturę dokładnych opisów badań pogłębiających te sformułowania. Kluczowa jednak idea dotyczy troski o interwencję tak edukującą, aby konstrukcje i operacje analogiczne podlegały transformacji. Chodzi o to, aby proste doświadczenie z życia codziennego i elementarnych sytuacji nie było wyznacznikiem poziomu zaawansowania operacji umysłowych pozbawionych skojarzeń paradoksalnych i uwalniających od stylu opartego na pułapkach i przeszkodach, jakie wspomniane typy analogii niosą. Semantycznie też są one zbyt ubogie dla uwzględ- 
niania złożoności sytuacji spoza doświadczenia codziennego, a zatem potocznego, czasem wręcz naiwnego, a przez to groźne. Autor jednak podkreśla dla kształcenia elementarnego wagę wspomagania nauczania analogiami, z troską o wydobywanie powiązań na nich opartych, ale dla przechodzenia do klasyfikacji charakteryzującej pojęcia bardziej ogólne sytuacyjnie. Stąd waga wysiłku określonego mianem „rekodowania semantycznego”, odkrywającego znaczenie jednego miejsca, zjawiska przez odniesienie do innego, pozwalającego na abstrahowanie od różnic w kierunku odnajdywania tego, co łączy w planie bardziej ogólnym, w trosce o większą spójność (cohérence) w procesie transformacji wiedzy dostępnej uczniom. Stąd nie dziwi teza ogólna, kończąca rozważania, że jest pewna równoległość między dynamikami zmian obserwowanych w obszarze edukacji oraz na polu aktywności profesjonalnej szerzej. Przez to też czytamy, że „podejście analogiczne” jest w stanie swoją dynamiką tworzyć „płodną ramę dla badania transformacji aktywności” w jej ogólności. Kluczową cechą pojęć, pozwalającą na ich transformację są „porowatości" (porosités) przepuszczające impulsy rozwojowe, stanowiące podstawę dla nowej epistemologii, jaką podejście to sugeruje.

\section{Uwagi na zakończenie}

Ta próba refleksyjnego ogarnięcia przekroju problemowego książki, z racji zbyt słabej dostępności języka francuskiego w Polsce, musiała być stosunkowo obszerna, mimo z konieczności nadmiernej skrótowości w wielu ciekawych kwestiach. Najważniejsze dla zarysowanej perspektywy jest dla mnie szukanie powiązań między biegunami tytułowymi książki, które jednak bardziej staram się widzieć w kategoriach wykorzystywania operatora versus sprzęgającego napięcia w polu struktur (działania, myślenia, budowania całości) wymagające zarazem troski o dynamikę oraz stabilność (Witkowski 2015, 2018). Pojawia się więc w tle projektowanej przestrzeni epistemologicznej konieczność widzenia metarelacji, zbyt skąpo oddawanych przez ukośnik tytułowy (Représenter/transformer), a stanowiących o napięciu w układzie powiązań: dynamizować versus stabilizować, ważnym dla funkcjonalności wiedzy wpisanej zarówno w globalne struktury procesów i aktywności instytucjonalnej, jak i jednostkowych strategii oraz podejść tu prześledzonych Przytoczone powyżej treści tej książki dostarczają miejscami zaskakującego materiału dla takiego wysiłku reorganizacji perspektywy rozumienia i praktyki aktywnego modyfikowania świata działań ludzkich. Upominanie się o nową epistemologię wpisane jest tu nader inspirująco w projektowaną perspektywę „antropologii aktywności profesjonalnej", a jest to znaczącym wkładem Jean-Marie Barbiera i jego partnerów/współpracowników o zasięgu światowym, z udziałem Ewy Marynowicz-Hetki, co sprawia satysfakcję piszącemu dodatkowo. 


\section{Bibliografia}

Bachelard G. (1940) La philosophie du non. Essai d'une philosophie du nouvel esprit scientifique, Paris, Presses Universitaires de France.

Bachelard G. (1980) Le matérialisme rationnel, Paris, Presses Universitaires de France.

Bachelard G. (2000) Filozofia, która mówi nie. Esej o filozofii nowego ducha w nauce, tłum. J. Budzyk, Gdańsk, Słowo/obraz terytoria.

Barbier C. (2018) Invariants de changements et transformaions d'invariance : deux objets privilegiés pour l'ergonomie ? w: Représenter/transformer. Débats en analyse des activités. J.-M. Barbier, M. Durand (red.), współpr. C. Cohen, M.-L. Vitali, Paris, L'Harmattan, s. 25-40.

Barbier J.-M. (2016) Leksykon analizy aktywności. Konceptualizacje zwyczajowych pojęć, tłum. i oprac. E. Marynowicz-Hetka, Łódź, Wydawnictwo Uniwersytetu Łódzkiego.

Barbier J.-M. (2017) Vocabulaire d'analyse des activités. Penser les conceptualisations ordinaires - Essai, Paris, Presses Universitaires de France.

Barbier J.-M. (2018) Penser en termes de transformations ? w: Représenter/transformer. Débats en analyse des activités, J.-M. Barbier, M. Durand (red.), współpr. C. Cohen, M.-L. Vitali, Paris, L'Harmattan, s. 11-23.

Bombaire M. (2018) Figurer les gestes techniques w: Représenter/transformer. Débats en analyse des activités, J.-M. Barbier, M. Durand (red.), współpr. C. Cohen, M.-L. Vitali, Paris, L'Harmattan, s. 215-227.

Cuhna Ch., Santos G., Cunha D. (2018) Produire des savoirs sur le travail pour transformer l'activité w: Représenter/transformer. Débats en analyse des activités, J.-M. Barbier, M. Durand (red.), współpr. C. Cohen, M.-L. Vitali, Paris, L’Harmattan, s. 65-86.

Durand M., Salini D. (2018) Transformer sa vie en mettant en scène son activité passée. Les représentations de l'activité dans le „Théâtre du Vécu” w: Représenter/transformer. Débats en analyse des activités, J.-M. Barbier, M. Durand (red.), współpr. C. Cohen, M.-L. Vitali, Paris, L'Harmattan, s. 43-63.

Dutoit M. (2018) Se représenter l'autre en mouvement. De l'interactivité professionnelle-s/enfants dans un Centre d'Action Medico-Sociale Précoce w: Représenter/transformer. Débats en analyse des activités, J.-M. Barbier, M. Durand (red.), współpr. C. Cohen, M.-L. Vitali, Paris, L'Harmattan, s. 89-101.

Freire P. (1972) Pedagogy of the Oppressed, trans. M. Bergman, Ramos, Peunguin Books. 
Guillerme A. (2018) La formalisation du geste technique en France à la fin du 18ème siècle w: Représenter/transformer. Débats en analyse des activités, J.-M. Barbier, M. Durand (red.), współpr. C. Cohen, M.-L. Vitali, Paris, L’Harmattan, s. 203-214.

Harbonnier N. (2018) Représenter le mouvement pour le transformer w: Représenter/ transformer. Débats en analyse des activités, J.-M. Barbier, M. Durand (red.), współpr. C. Cohen, M.-L. Vitali, Paris, L'Harmattan, s. 103-128.

Kostyło H. (2011) Przesłanie „Pedagogiki uciśnionych” Paolo Freire, „Forum Oświatowe", nr 2 (45), s. 7-26.

Lahlou S. (2018) Installer l'activité pour la réguler w: Représenter/transformer. Débats en analyse des activités, J.-M. Barbier, M. Durand (red.), współpr. C. Cohen, M.-L. Vitali, Paris, L'Harmattan, s. 131-157.

Machado L., Tomasi A. (2018) La subjectivation par les objets techniques w: Représenter/transformer. Débats en analyse des activités, J.-M. Barbier, M. Durand (red.), współpr. C. Cohen, M.-L. Vitali, Paris, L’Harmattan, s. 159-181.

Marynowicz-Hetka E. (2018) Transformations invisibles/silencieuses et champs du travail social w: Représenter/transformer. Débats en analyse des activités, J.-M. Barbier, M. Durand (red.), współpr. C. Cohen, M.-L. Vitali, Paris, L’Harmattan, s. 183-199.

Marynowicz-Hetka E. (2019) Pedagogika społeczna. Pojmowanie aktywności w polu praktyki, Łódź, Wydawnictwo Uniwersytetu Łódzkiego.

Marynowicz-Hetka E. (2020) Social Pedagogy. Comprehending Activity in the Field of Practice, trans. by Martin Hinton, Beau Bassin, Labert Academic Publishing.

Représenter/transformer. Débats en analyse des activités (2018) J.-M. Barbier, M. Durand (red.), współpr. C. Cohen, M.-L. Vitali, Paris, L’Harmattan.

Sander E. (2018) Transformer l'inconnu par le connu. Constructions et interventions analogiques pour les apprentissages scolaires w: Représenter/transformer. Débats en analyse des activités, J.-M. Barbier, M. Durand (red.), współpr. C. Cohen, M.-L. Vitali, Paris, L'Harmattan, s. 259-279.

Silva da E. R. (2018) Le „passage à l'acte” professionnel w: Représenter/transformer. Débats en analyse des activités, J.-M. Barbier, M. Durand (red.), współpr. C. Cohen, M.-L. Vitali, Paris, L'Harmattan, s. 231-258.

Witkowski L. (2015) Versus. O dwoistości strukturalnej faz rozwoju w ekologii cyklu życia psychodynamicznego modelu Erika Hamburgera Eriksona, Kraków, Oficyna Wydawnicza „Impuls”.

Witkowski L. (2018), Humanistyka stosowana. Wirtuozeria, pasje, inicjacje. Profesje społeczne versus ekologia kultury, Kraków, Oficyna Wydawnicza „Impuls”. 


\section{Cross-sections of Professionalism: Representations versus Transformations}

\section{Summary}

The essay highlights selected areas of professional activity, analytically reporting the content of the volume: Représenter/transformer. Débats en analyse des activités. Ouvrage coordonné par Jean-Marie Barbier et Marc Durand. Avec la collaboration de Claude Cohen et de Marie-Laure Vitali, L'Harmattan. Paris 2018. In this article, the author takes up selected aspects of the meta-narrative analysis concerning the six parts of the book, in which 13 texts are collected on various relationships between the title parts of the book. The text attempts to use the main features of the authors' deliberations to outline the problems of the field of professional activity in terms of their approach (representation), with faithful use of the narratives reported.

This aspect of the cited contents turns out to be particularly important, highlighting the categories constituting a new conceptual screen for the projection, thanks to which the phenomena concerning practical changes become visible, which are still only breaking through in the research perspectives and in reflection in action. The essay text ends with critical remarks and postulates for further transformation of the emerging discourse. The international character of the discussed research project is emphasized, crowned with this publication, collecting the works of authors from: Brazil, France, Canada, Poland, Switzerland, Great Britain and Italy. Polish pedagogy is represented only by Ewa Marynowicz-Hetka in this epistemologically important text.

The problem area of the article, according to the structure of the chapters in the book, includes the following parts: Towards an anthropology of action; The issue of invariants and regularity; Theatrization, metaphorization and change of the course of life; Knowledge-dependent work transformation; Carnality as representation and transformation medium; Implications of representation/transformation in the context of dance; Installations as constraints of transformation; Technical subjects as a medium of empowerment; The issue of invisibility and the silent nature of transformation; "Technical gestures" and their transformations; Transitions through the levels (styles) of professional activities; Analogies in the service of transformation; Concluding remarks. The keywords are: transformations, technicality, representations, levels, invariants, complexity.

\section{Coupures transversales de professionnalisation : représen- tations versus transformations}

\section{Résumé}

Dans cet essai, nous mettons en évidence des espaces sélectionnés d'activités professionnelles en rapportant de façon analytique le contenu du volume: Représenter/transformer. Débats en analyse des activités. Ouvrage coordonné par 
Jean-Marie Barbier et Marc Durand. Avec la collaboration de Claude Cohen et de Marie-Laure Vitali, L'Harmattan. Paris 2018. Nous y abordons certains aspects de l'analyse méta-narrative, concernant les six parties du livre, contenant 13 textes sur des relations diverses en rapport avec l'intitulé du livre. Le texte essaie d'utiliser les principales idées des auteurs pour esquisser les problèmes du champ d'activité professionnelle, tout en gardant leur conception (représentation), afin de refléter le plus fidèlement possible les récits rapportés.

Ce qui est particulièrement important c'est cet aspect qui met en évidence les catégories constituant un nouvel écran/cadre conceptuel pour une projection faisant apparaître des phénomènes de transformation pratique qui apparaissent à peine dans les perspectives de recherche et de réflexion en action.

Le texte de l'essai se termine par les remarques critiques et les postulats de transformation du discours émergeant. Il souligne le caractère international du projet de recherche en question, couronné par cette publication et rassemblant des œuvres d'auteurs du Brésil, de France, du Canada, de Pologne, de Suisse, du Royaume-Uni et d'Italie. La pédagogie polonaise y est représentée par Ewa Marynowicz-Hetka dans ce texte important du point de vue épistémologique.

Le champ de problèmes de l'article, selon la structure des chapitres du livre, comprend les parties suivantes : Vers l'anthropologie de l'action; la question des invariants et de la régularité ; la théâtralisation, la métaphore et le changement du cours de la vie ; les transformations du travail par rapport au savoir ; le physique en tant que représentation et médium transformateur ; les conséquences de la représentation/transformation dans le contexte de la danse ; les installations comme limites de transformation; les objets techniques en tant que moyen d'autonomisation ; la question de l'invisibilité et du caractère silencieux de la transformation ; les "gestes techniques" et leur transformation ; passer par les niveaux (styles) des activités professionnelles ; les analogies au service de la transformation ; remarques finales.

\section{Cytowanie}

Witkowski L. (2021) Przekroje profesjonalności: reprezentacje versus transformacje, „Nauki o Wychowaniu. Studia Interdyscyplinarne” 2(13), 275-298, https://doi.org/ 10.18778/2450-4491.13.16 